\title{
Isolation and Characterization of Thermophilic Bacteria Indigenous to Al-Ahsa Desert
}

\author{
Ahmed Anwar Al-Mulla ${ }^{1}$ (D) and Ashraf Khalifa ${ }^{2,3 *}$ (D) \\ ${ }^{1}$ Alkifah Academy, 8767, Al-Hufuf and Al-Mubarraz 36361, Saudi Arabia. \\ ${ }^{2}$ Biological Sciences Department, College of Science, King Faisal University, Al-Ahsa 31982, Saudi Arabia. \\ ${ }^{3}$ Botany and Microbiology Department, Faculty of Science, University of Beni-Suef 65211, Beni-Suef, Egypt.
}

\begin{abstract}
Deciphering the biological resources across the Saudi niches is highly recommended for the prosperity. To this end, the aim of the current work was to isolate thermophilic bacteria from unexplored areas of Al-Ahsa region, and investigate their phenotypic characteristics. Three soil samples were collected from different desert sites of Al-Ahsa region. Thermophilic bacteria were isolated directly for soil samples into Thermus medium broth as a standard method. Single colonies of the actively growing bacterial isolates were preserved in $20 \%$ glycerol then kept at $-80^{\circ} \mathrm{C}$. The isolates were screened for production of thermostable enzymes using the commercially available kit API20E strip (bioMerieux, Marcy l'Etoile, France). Incubation were carried out at $50^{\circ} \mathrm{C}$. It can be concluded that thermophilic bacteria in Al-Ahsa region harbor novel thermostable enzymes that might have biotechnological applications, in future.

Keywords: Thermophilic bacteria, Al-Ahsa, Phenotypic characterization
\end{abstract}

*Correspondence: Ashraf_zaky2002@yahoo.com; 966547539615

(Received: June 22, 2020; accepted: August 08, 2020)

Citation: Al-Mulla AA, Khalifa A. Isolation and Characterization of Thermophilic Bacteria Indigenous to Al-Ahsa Desert. J Pure Appl Microbiol. 2020;14(3):2157-2163. doi: 10.22207/JPAM.14.3.56

(C) The Author(s) 2020. Open Access. This article is distributed under the terms of the Creative Commons Attribution 4.0 International License which permits unrestricted use, sharing, distribution, and reproduction in any medium, provided you give appropriate credit to the original author(s) and the source, provide a link to the Creative Commons license, and indicate if changes were made. 


\section{INTRODUCTION}

Bacteria are ubiquitous prokaryotic microorganisms. The term thermophilic bacteria is applied to the group of bacteria that can grow optimally at a higher temperature range $\left(45^{\circ} \mathrm{C}\right.$ $-70^{\circ} \mathrm{C}$ ) than usual. The reason of their survival is due to the production of thermostable bioactive compounds, which are both made at high temperatures (ALrumman et al., 2018). Therefore, thermophilic bacteria are attractive research candidates as they produce bio-based chemicals, which have potential biotechnological applications (Marcano-Velazquez et al., 2019).

Hot springs are very hot places where thermophilic bacteria exist (ALrumman, 2018). An investigation has been conducted on thermophilic bacteria obtained from hot springs located in the south of Saudi Arabia. In that study, approximately $60 \%$ (50 out of 84 isolates have exhibited antibacterial activity against human pathogenic bacterial species; Shigella flexneri, Klebsiella pneumonia Candida albican Proteus mirabilis and Staphylococcus aureus (ALrumman et al., 2018). These findings suggest that the raise of awareness is needed because the isolating thermophilic bacteria could be promising candidates for obtaining novel biologically-active molecules of biotechnological applications (ALrumman et al., 2018).

Moving on, enzymes have been used in everyday products like cheese detergents and the production of leather. Enzymes have key roles in triggering such applications (Rigoldi et al., 2018). Enzymes are proteins catalyze specific chemical reactions in biological systems (Lee \& deMan, 2018). One of these enzymes include the thermostable enzymes where they depend on thermophilic bacteria. Thermostable enzymes are extremophilic molecules that have various applications in industry and medicine (Kambourova, 2018).

It has been reported that Bacillus amyloliquefaciens produced thermostable enzymes amylase, lipase and protease that exhibitated obvious activities $55^{\circ} \mathrm{C}$. Such enzymes could play a milestone role in production of biofuel in the cleaning and greening stages (Devaraj et al., 2018). Thermophilic bacteria attract the researchers' attention for their unique capabilities to grow at elevated temperatures. Cellular components and bioactive macromolecules (e.g., enzymes) of these bacteria exhibit an incredible stability to heat than those of the mesophilic bacteria. Thermostable enzymes are a milestone in biotechnological applications such as food and paper industry, bioremediation,

Despite many studies have reported thermophilic bacteria in various ecological niches, their diversity is not entirely covered. Furthermore, due to their ecofriendly nature, promising efficiency and the mild reaction conditions, thermostable enzymes significantly exceed the chemical catalysts in industrial purposes. Additionally, little is known about thermophilic bacteria and their thermostable enzymes in AlAhsa. Therefore, it is of interest to explore the thermophilic bacteria indigenous to Al-Ahsa soils and assess their potentials for production of thermostable enzymes that can be exploited in industrial applications. The biological question is; does Al-Ahsa desert harbor thermophilic bacteria that are capable of producing thermostable enzymes for exploitation in new biotechnological applications.

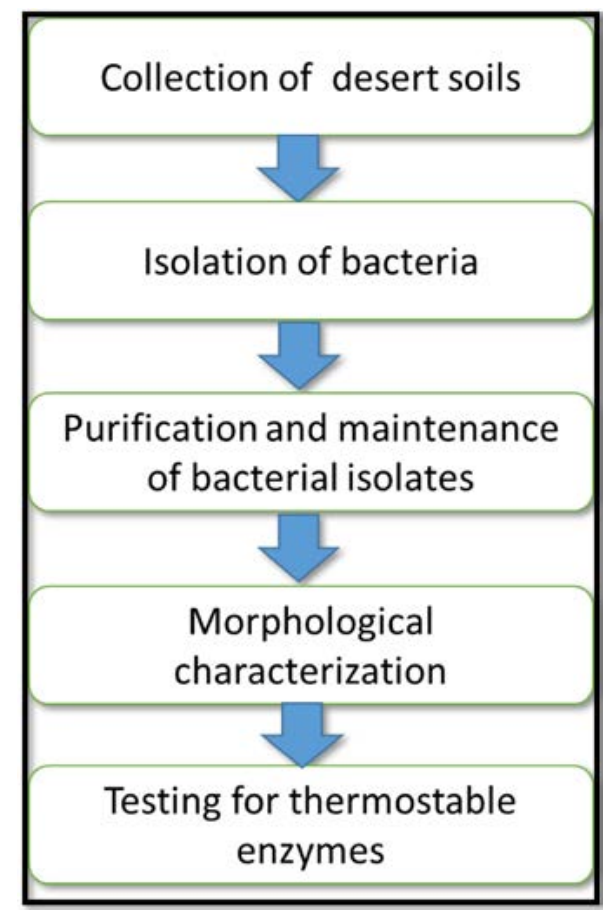

Fig. 1. Design of the experimental work carried out in the current study. 
Table 1. Sand Samples Addresses

\begin{tabular}{|c|c|c|c|c|}
\hline \multirow[b]{2}{*}{ Sample } & \multirow[b]{2}{*}{ Name } & \multirow[b]{2}{*}{ Address } & \multicolumn{2}{|c|}{ Coordinates } \\
\hline & & & Latitude & Longitude \\
\hline 1 & $\begin{array}{l}\text { Juatha } \\
\text { Desert }\end{array}$ & $\begin{array}{l}\text { Al Kulabiyah, } \\
\text { Juatha } 36348, \\
\text { Saudi Arabia }\end{array}$ & 25.46399 & 49.6705609 \\
\hline 2 & $\begin{array}{l}\text { Al Taraf } \\
\text { Desert }\end{array}$ & $\begin{array}{l}\text { Al Taraf, } 36353 \text {, } \\
\text { Saudi Arabia }\end{array}$ & 25.4676068 & 49.678829 \\
\hline 3 & $\begin{array}{l}\text { Sharq } \\
\text { Desert }\end{array}$ & $\begin{array}{l}\text { 4735, Al Hufuf } \\
\text { and Al Mubarraz } \\
36443, \text { Saudi } \\
\text { Arabia }\end{array}$ & 25.2847099 & 49.6192309 \\
\hline
\end{tabular}

\section{MATERIALS AND METHODS}

In order to answer the biological question that was already asked earlier, a design describing the various steps in methodology was proposed (Fig. 1). As can be seen in the flowchart, collection of desert soils from different places within Al-Ahsa region was the first step. Isolation of thermophilic bacterial isolates came second. The isolated bacteria were purified in order to obtain single colonies that represent potential single species and preserved, in the third step. Morphological characterization of the bacterial isolates based on the Gram reaction was carried out in the fourth steps. Finally, the bacterial isolates were tested for their abilities to produce thermostable enzymes using the kit API20E strip (bioMerieux, Marcy l'Etoile, France).

\section{Collection of soil samples}

Three soil samples were collected from different desert sites of Al-Ahsa region as shown in Table 1.

\section{Isolation of thermophilic bacteria}

Thermophilic bacteria were isolated directly from soil samples into Thermus medium
1033 broth (Ibrahim and El-diwany 2007) after appropriate dilutions in saline solutions. Flasks were incubated at $45^{\circ} \mathrm{C}$ for $72 \mathrm{~h}$ with shaking. After incubation, aliquots of the bacterial culture will be streaked into Thermus medium 1033 plates in order to get single colonies.

\section{Preservation of the bacterial isolates}

Actively growing bacterial isolates were preserved in $20 \%$ glycerol then kept at $-80^{\circ} \mathrm{C}$.

Morphological characterization of the bacterial isolates

In order to determine the shape and the Gram reaction, bacterial isolates were stained using Gram staining following the standard protocol.

\section{Testing for thermostable enzymes}

The bacterial isolates were tested for their ability to produce thermostable enzymes using the commercially available kit API20E strip (bioMerieux, France) following the instructions of the manufacturer. Strips were incubated at $45^{\circ} \mathrm{C}$ for $24 \mathrm{~h}$. The experiment will be carried out in triplicate. Water instead of bacterial culture will serve as negative control.

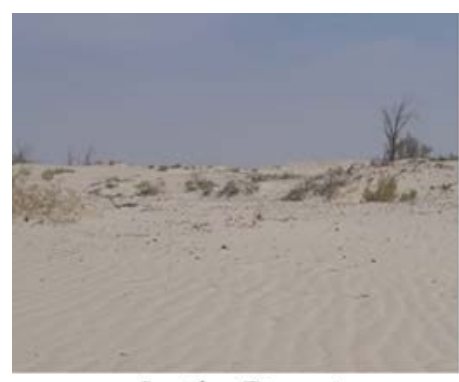

Juatha Desert

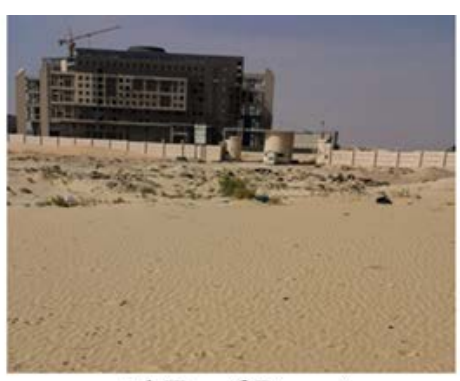

Al Taraf Desert

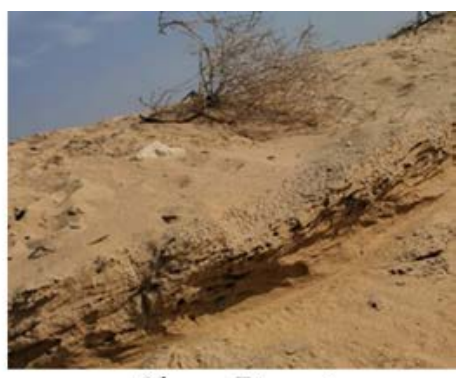

Sharq Desert

Fig. 2. Sites of Collections 
Details about the substrates and enzymes to be tested are presented in table 1.

\section{RESULTS AND DISCUSSION Collection of soil samples}

In this study, three desert soils were collected from three different sites in Al-Ahsa region. Details about the sites of collection were presented in Table 1 and Fig. 2.

Isolation and purification of thermophilic bacteria

Five bacterial isolates from the three desert, after incubation period of $48 \mathrm{~h}$ at $45^{\circ} \mathrm{C}$ (Fig. 3). To avoid redundancy, three purified bacterial isolates were selected for further characterization, based on the similarities in colony appearance. The isolates were designated NASA1(from Juatha desert), KSA3A and KSA3B (from Sharq desert) (Fig. 3 and 4 ). The isolates exhibited good growth at $45^{\circ} \mathrm{C}$ and $50^{\circ} \mathrm{C}$ indicating their thermophilic nature. Morphological characterization

The results of Gram staining were presented in Fig. 5. NASA1 and KSA3B were Gram-positive rods, while KSA3A was Gramnegative rods, as they appeared purple and red in colour, respectively. The differences in reaction towards Gram staining in generally attributed to the differences in the chemical structure of the bacterial cell walls. Gram-positive bacteria has more peptidoglycan and less lipids that the Gramnegative bacteria possessed.

\section{Testing for thermostable enzymes}

The results of the biochemical characterization of the bacterial isolates as obtained using the kit API20E strip (bioMerieux, Marcy l'Etoile, France) were presented in Fig. 6 . The change in colour is an indication of the substrate utilization and therefore the corresponding enzymes production. As can be seen in Fig. 6, NASA1, KSA3A and KSA3B, reacted positively to 8,7 and 6 out of 20 testers examined, respectively (Table 2 ). The three bacterial isolates were able to utilize arginine, lysine, ornithine and glucose. This highlighted that the ability of our isolates in producing thermostable enzyme that were involved in the utilization of the substrates tested; they were to produce Lysine decarboxylase, Ornithine decarboxylase, arginine dihydrolase and glucokinase. The first three enzymes have potential in biogeochemical cycles via their ability to metabolize the relevant amino acids and their derivatives. However, glucokinase is the key enzyme in glucose metabolism. Glucose

Table 2. Results of the API 20 NE kit

\begin{tabular}{llllll}
\hline No. & Substrate & $\begin{array}{l}\text { Enzyme involved/ } \\
\text { reaction tested }\end{array}$ & NASA1 & KSA3A & KSA3B \\
\hline 1 & ONPG $*$ & Beta-galactosidase & - & - & - \\
2 & Arginine & Arginine dihydrolase & + & + & + \\
3 & Lysine & Lysine decarboxylase & + & + & + \\
4 & Ornithine & Ornithine decarboxylase & + & + & + \\
5 & Citrate & Citrate utilization & - & + & + \\
6 & Na thiosulfate & HeS production & - & - & - \\
7 & Urea & Urease & - & + & + \\
8 & Tryptophan & Deaminase & - & - & - \\
9 & Tryptophan & Indole production & - & - & - \\
10 & Na pyruvate & Acetoin production & - & - & - \\
11 & Charcoal gelatin & Gelatinase & - & - & + \\
12 & Glucose & Fermentation/oxidation & + & + & - \\
13 & Mannitol & Fermentation/oxidation & - & + \\
14 & Inositol & Fermentation/oxidation & - & - & - \\
15 & Sorbitol & Fermentation/oxidation & - & - \\
16 & Rhamnose & Fermentation/oxidation & + & - & - \\
17 & Sucrose & Fermentation/oxidation & - & - & - \\
18 & Melibiose & Fermentation/oxidation & + & - & - \\
19 & Amygdalin & Fermentation/oxidation & + & - \\
20 & Arabinose & Fermentation/oxidation & + & - & - \\
& & & & - \\
\hline
\end{tabular}


is an important source for ethanol formation under anaerobic conditions. Unlike other isolates, NASA1 showed an obvious ability to consume Melibiose, Amygdalin, and Arabinose but couldn't produce urease. KSA3A was the only isolate that could metabolize mannitol. Such diversity with respect to various substrates tested highlighted a metabolic variability among the isolates under consideration.

The enzymes involved in mannitol catabolism are mannitol-2-dehydrogenase and fructokinase. It is worth mentioning that mannitol, sugar alcohol, accounts up to $30 \%$ of the dry weight of many brown algae. Therefore, obtaining a local

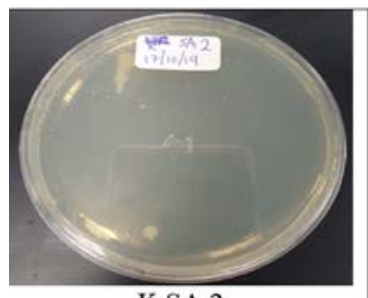

K SA 2

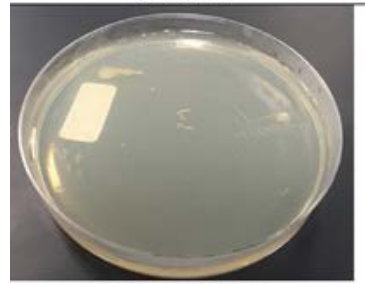

K SA 2 (Inside)

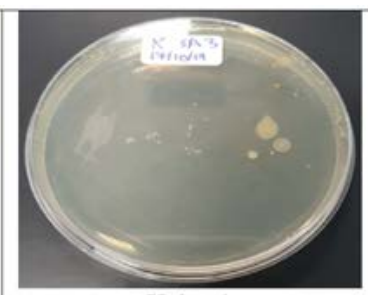

K SA 3

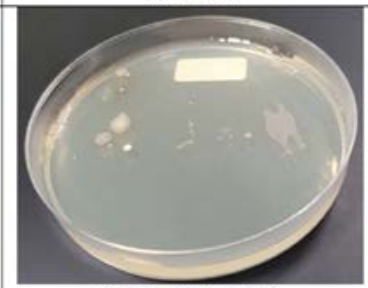

K SA 3 (Inside)

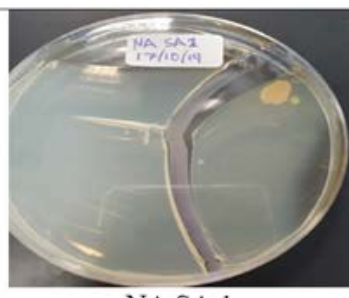

NA SA 1

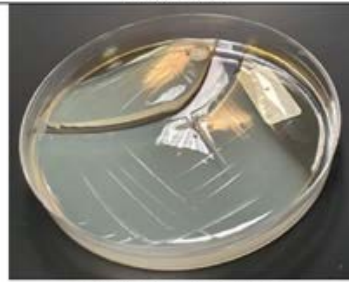

NA SA 1 (Inside)

Fig. 3. Isolation of bacterial from desert soils

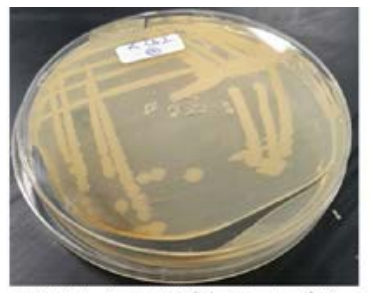

K SA 2 A (With Bacteria)

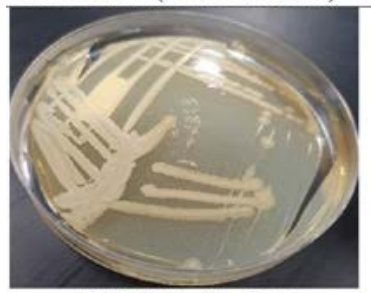

K SA 2 A (Inside)

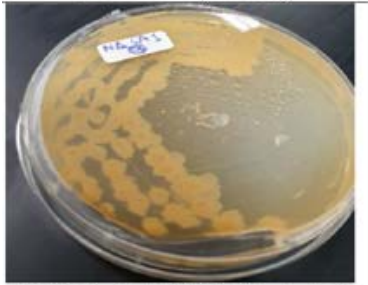

NA SA 1 A (With Bacteria)

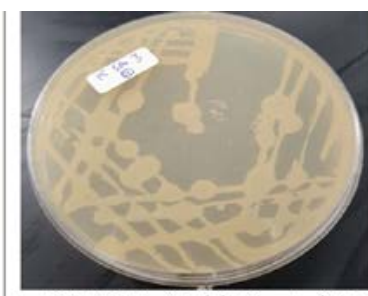

K SA 3 A (With Bacteria)

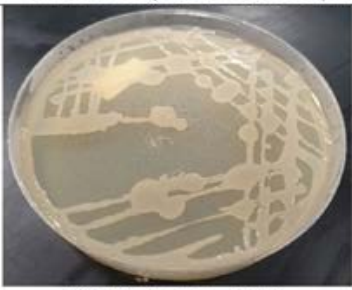

K SA 3 A (Inside)

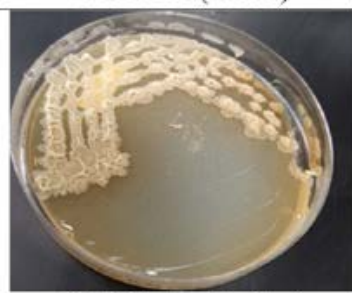

NA SA 1 A (Inside)

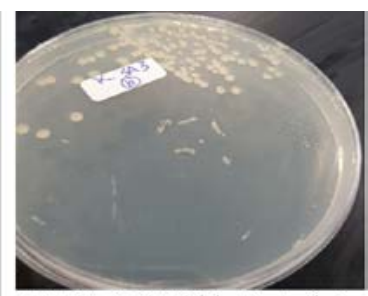

K SA 3 B (With Bacteria)

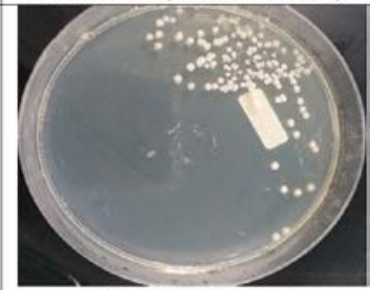

K SA 3 B (Inside)

Fig. 4. Purification of bacterial isolates. 
bacterial isolate that can metabolize mannitol as an initial step for biofuel production from seaweeds in coastal regions. This will contribute significantly in converting the wastes into energy via a biological bioreactor. Renewable sources of energy is a key goal of the development.

To obtain local and efficient thermophilic bacterial isolates from Al-Ahsa desert is of premium importance in production of biotechnological applications such as biofuel production of wastes of seaweeds in a multistep process. Invaded bacterial isolates usually fail to cope with the prevailing conditions in Al-Ahsa region. The bacterial isolates could act as a collaborative team to execute the dedicated tasks efficiently in a sequential manner.

\section{CONCLUSION}

Three thermophilic bacterial were successfully isolated from the local desert soils in Al-Ahsa region. Isolation of novel thermophilic bacterial isolates from previously unexplored
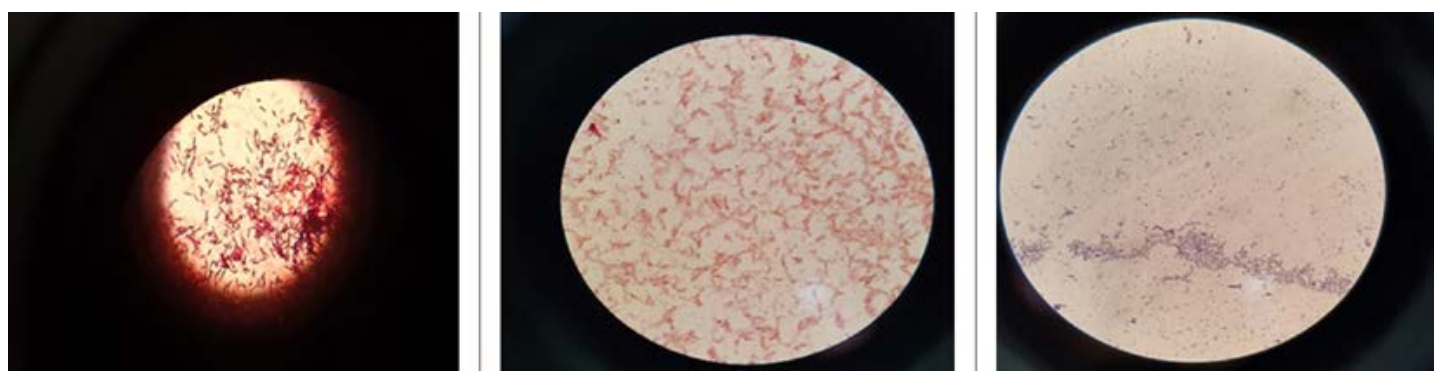

Fig. 5. Gram reaction of the bacterial isolates

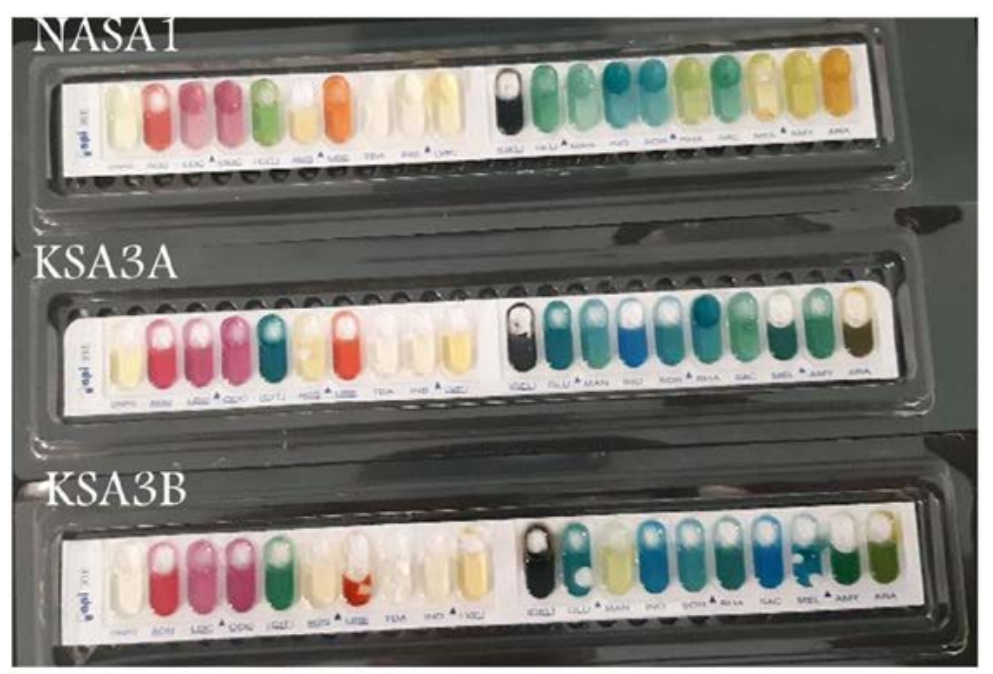

\section{Positive results}

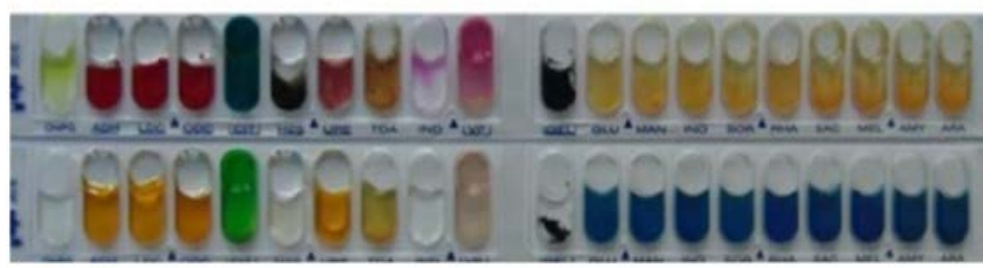

\section{Negative results}

Fig. 6. Results of the API 20 NE kit for the three bacterial isolates. Positive and negative controls are also presented for comparison. 
desert sites in Al-Ahsa represent a step forward in shedding the light on the diversity of thermophilic microorganisms. This could lead to identification of new bacterial taxa and enzymes. Additionally, testing the isolated bacteria for their abilities to produce 20 different enzymes in one step can be viewed as a creative step in the current study. Furthermore, deciphering the metabolic machinery of the bacterial isolates for thermostable enzymes may lead to novel industrial application of such enzymes in future. Searching of alternative renewable sources of energy is well-fitted with current study. The bacteria exhibited a profound ability to produce certain thermostable enzymes that could be exploited in production of biofuel. For instance, ethanol could be produced from mannitol, a dominant sugar alcohol in brown algae using the mannitol-2-dehydrogenase and fructokinase. The conditions should be optimized for maximum production of bioethanol, in future. Such strains are considered as precious bacterial wealth for renewable energy, to achieve the goals of the development vision.

\section{ACKNOWLEDGMENTS}

We would like to express our heartfelt thanks to Biological Sciences Department, College of Sciences, King Faisal University, for providing access to the Microbiology Laboratory to conduct this work.

\section{CONFLICT OF INTEREST}

The authors declare that there is no conflict of interest.

\section{AUTHORS' CONTRIBUTION}

AK designed the experiments, analyzed the data and wrote the manuscript. AA performed the experiments, compiled information from the literature, and designed the Fig.s and tables. All authors read and approved the manuscript.

\section{FUNDING}

None.

\section{ETHICS STATEMENT}

Not applicable.

\section{DATA AVAILABILITY}

All datasets generated or analyzed during this study are included in the manuscript.

\section{REFERENCES}

1. Aziz GM, Ali HM. Purification and Characterization of Agarase from Bacillus sp., H12. Curr Res J biol Sci. 2013;1:13-18. doi: 10.19026/crjbs.5.5466

2. Devaraj K, Aathika S, Periyasamy K, et al. Production of thermostable multiple enzymes from Bacillus amyloliquefaciens KUB29. Natural Product Research. 2019;33(11):1674-1677. doi: 10.1080/14786419.2018.1425857

3. Ibrahim ASS, El-diwany Al. Isolation and identification of new cellulases producing thermophilic bacteria from an Egyptian hot spring and some properties of the crude enzyme. Aust J Basic Appl Sci. 2007;1(4):473478.

4. Kambourova M. Thermostable enzymes and polysaccharides produced by thermophilic bacteria isolated from Bulgarian hot springs. Engineering in Life Sciences. 2018;18(11):758-767. doi: 10.1002/ elsc.201800022

5. Lee CY, deMan JM. Enzymes. In: Principles of Food Chemistry. Food Science Text Series. Springer, Cham. 2018. doi: 10.1007/978-3-319-63607-8

6. Marcano-Velazquez JG, Lo J, Nag A, Maness P, C, Chou KJ. Developing Riboswitch-Mediated Gene Regulatory Controls in Thermophilic Bacteria. ACS Synthetic Biology. 2019;8(4):633-640.doi: 10.1021/ acssynbio.8b00487

7. Rigoldi F, Donini S, Redaelli A, Parisini E, Gautieri A. Review: Engineering of thermostable enzymes for industrial applications. APL Bioengineering. 2018;2(1):011501.doi: 10.1063/1.4997367 